\title{
Synthesis, Structural Analysis and Antimicrobial Activities of Novel Water Soluble Ionic Liquids Derived from $\mathbf{N}$-Heterocyclic Carbene Salts
}

\author{
Ahmet Kunduracıoğlu, ${ }^{1, *}$ Özkan Gübe, ${ }^{2}$ Elif Esin Hameş-Kocabaş, ${ }^{2}$ Volkan Eyüpoğlu, ${ }^{3}$ Fatih Sönmez ${ }^{4}$
}

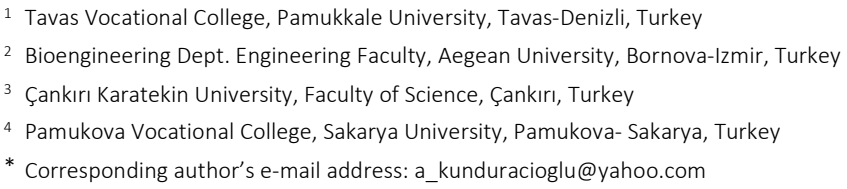

RECEIVED: February 4, 2015 * REVISED: March 14, 2016 * ACCEPTED: April 1, 2016

Abstract: Six N-heterocyclic Carbene based Ionic Liquids (ILS) have been synthesized by conventional methods. The ILs were spectroscopically characterized by NMR and FT-IR techniques. Their in vitro antimicrobial activities were determined towards gram-positive and gram-negative bacterias and yeast strains using minimum inhibition concentration (MIC) assay. The best inhibition performances were obtained with compound 1 due to its more hydrophilic nature compared with the others. It exhibited $1 \mathrm{mg} \mathrm{L}^{-1} \mathrm{MIC}$ value against to the most bacteria while the others showed $4 \mathrm{mg} \mathrm{L}^{-1}$.

Keywords: ionic liquids, $\mathrm{N}$-heterocyclic carbenes, antimicrobial activity, $\mathrm{N}$-functional substituents.

\section{INTRODUCTION}

$\mathbf{T}$ he term "Green chemistry" has been accepted as the movement towards environmental friendly chemical processes and products for a recent decade. Researchers in all over the world have attempted considerable efforts to explore novel, environmental-friendly chemicals or materials that they should contribute green chemistry or sustainable chemistry concepts. For achieving this aim, ionic liquids (ILs) are a very best class of novel materials. Ionic liquids are known as a class of compounds, composed of an anion and cation like salts. Their melting point are below $100{ }^{\circ} \mathrm{C}$. ILs have attracted an increasing attention for their unique physical and chemical properties such as low vapor pressure, high polarities, electrical conductivities and nonflammability. ${ }^{[1-3]}$ Since they have multi-faced capabilities, every researcher has handled them from different aspects. In a study polymer material exhibited good solubility in Ils, ${ }^{[4]}$ while in some other studies the researchers tested ILs for their gas solubility. ${ }^{[5]}$ Therefore, they seem to be substituted for volatile organic compounds (VOCs) as different solvents. Besides, ILs and NHCs are used as regenerable reaction media and catalysts as metal-free salts and metal complexes. ${ }^{[6-9]}$ Also, some researchers have investigated them for their use in electrochemical applications too. ${ }^{[10-12]}$ Recent days they have been subjected to physical explorations because of their liquid phase properties such as liquid-liquid equilibrium and solubilities in other liquids, ${ }^{[13-15]}$ and tested NHC derivative ILs in supported membrane studies, extraction ${ }^{[16,17]}$ and in nanochemistry too. ${ }^{[18,19]}$

$\mathrm{N}$-heterocyclic carbenes (NHCs) are cyclic compounds containing one or mostly two $\mathrm{N}$ atoms in the main $\mathrm{C}$ ring (Figure 1). Many natural compounds such as caffeine and some amino acids like uraconic acid contain an $\mathrm{N}$ heterocyclic part, and NHC salts can be obtained by simple modifications of these natural compounds. (Figure 2). ${ }^{[20-22]}$

NHCs are mostly used as ligands for complexation reactions with transition metals like $\mathrm{Ag}(\mathrm{I}), \mathrm{Pd}(\mathrm{II}), \mathrm{Pt}(\mathrm{II})$, etc. The transition metal complexes of NHCs have been studied 


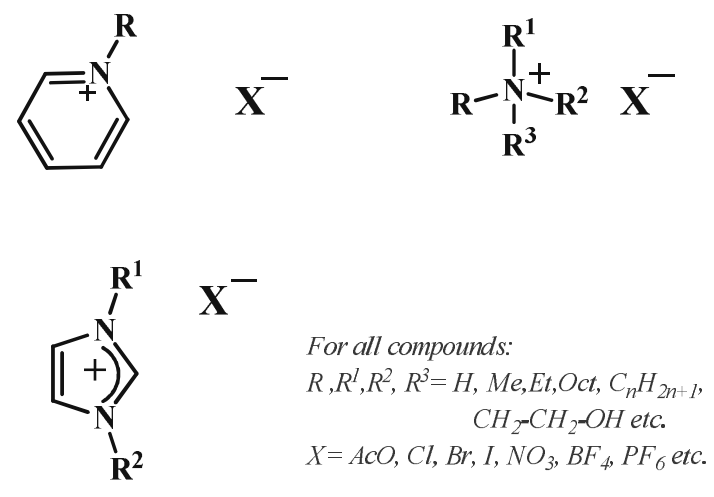

Figure 1. Examples for the types of ILs with $\mathrm{N}$ atoms.

and used as catalysts in various types of reactions such as polymerization, cyclization, reduction/oxidation, $\mathrm{C}-\mathrm{C}$ bond formation/cleavage, hydrosilylation, etc. ${ }^{[23]}$ Also, some researches have been conducted to utilize them as antimicrobial agents, ${ }^{[24]}$ as a surface antigen against hepatitis $B^{[25]}$ and even as anticancer drug candidates. ${ }^{[26]}$ The Antimicrobial activities of $\mathrm{Ag}(\mathrm{I})-\mathrm{NHC}$ complexes have been examined by Young et. al. since 2004 to present day. ${ }^{[27-30]}$ Roland et. al. also examined a series of $\mathrm{Ag}(\mathrm{I}) \mathrm{NHC}$ complexes for their antimicrobial properties as well. ${ }^{[31]}$ Metal-free NHC compounds and their derivatives were also examined for their biological and medicinal activities by many researchers. ${ }^{[32,33]}$ Antimicrobial activities and other pharmaceutical properties such as toxicity and antiseptic activities of ILs were pioneered by the research groups of lawa and GonzalezChavez rigorously. ${ }^{[34,35]}$ According to their studies, the primary advantage of the ILs in use is their well adjustable electronic, steric and other properties with changing the substituents and counter anions.

In this study, we have synthesized six novel ILs (compounds 1-6) and examined them for their antimicrobial activity.

\section{MATERIALS AND METHODS}

\section{Synthesis and Characterization of $\mathrm{N}$-Heterocyclic Carbene Salts}

Six novel $\mathrm{N}$-heterocyclic carbenes (as of now referred as 16) were synthesized by conventional methods described in R\&D. All materials and solvents such as imidazole, $N$-methyl imidazole, 2-bromoethaneamine hydrobromide were obtained from Sigma-Aldrich, Merck, and Alfa-Aesar and used without further purification. All synthesizing process were carried out in schlenk type tubes. Reaction progress was monitored by TLC (thin layer chromatography) using aluminum sheets coated with silica gel. Melting points were taken on a Yanagimito micro-melting point apparatus and uncorrected. IR spectra were measured on a Perkin Elmer<smiles>O=C(O)/C=C/c1c[nH]cn1</smiles>

Uraconic acid<smiles>Cn1c(=O)c2c(ncn2C)n(C)c1=O</smiles>

Caffeine

Figure 2. Examples for NHC compounds originated from natural compounds.

Spectrum100 FT-IR spectrometer. ${ }^{1} \mathrm{H}$ and ${ }^{13} \mathrm{C}$ NMR spectra were taken on spectrometer at VARIAN Infinity Plus 300 and $75 \mathrm{~Hz}$ respectively. ${ }^{1} \mathrm{H}$ and ${ }^{13} \mathrm{C}$ shifts were referenced to the internal deuterated solvent. The second peak in the acidic region referred that the "-. $\mathrm{HBr}$ " group has not left the molecule during the synthesis process.

\section{Antimicrobial Activity}

In vitro antimicrobial activity of the compounds (1-6) were investigated against microorganisms including three Grampositive bacteria (Staphylococcus aureus ATCC6538, vancomycin resistant Enterococcus faecium (VREF) DSM 13590, Bacillus subtilis ATCC 168, three Gram-negative bacteria (Escherichia coli 0157:H7 RSKK 234, Salmonella typhimurium CCM 5445, Pseudomonas aeruginosa ATCC 27853) and three yeast strains (Candida albicans ATCC 10231, Candida krusei ATCC 6258 and Candida tropicalis RSKK 665). The biological methods for cultivation of bacterial strains and determination of antimicrobial activity have been carried out according to $\mathrm{CLSI}^{[36]}$ and explained in following lines.

Bacterial strains were cultivated on Mueller-Hinton agar (MHA) and yeasts were grown on Sabouraud Dextrose Agar (SDA). The suspension of the test microorganisms was adjusted according to $0.5 \mathrm{cfu} \mathrm{mL}^{-1} \mathrm{McF}$ arland turbidimetric standards. The antimicrobial activity of each compound was evaluated by determination of the minimum inhibition concentration (MIC), defined as the lowest concentration of antimicrobial agent that inhibits growth after incubation. The assay was performed on the tested microorganisms by microdilution method according to Clinical and Laboratory Standards (CLSI). ${ }^{[36]}$ To prepare dilution series in the concentration range of $0.004-4 \mathrm{mg} \mathrm{mL}^{-1}, 20 \mu \mathrm{L}$ of all dilutions were transferred to the wells filled with $\mathrm{MHB}$ medium (180 $\mu \mathrm{L}$ final volume). Microorganism suspension $(20 \mu \mathrm{L})$ was then added to the wells. MHB medium without compound served as control. Gentamicin sulfate was used as reference antibiotic for bacteria and nystatin for yeasts. The cultures were incubated at $37^{\circ} \mathrm{C}$ for $24 \mathrm{~h}$. The growth of the microorganism was determined visually; the first well observed no visible growth was determined as the MIC. All experiments were performed in triplicate. 


\section{RESULTS AND DISCUSSION}

\section{Chemical Structures of ILs}

The synthesize reactions of the ILs tested in this study are shown together in the Scheme 3. Six ILs (NHC salts) were prepared and structurally characterized with $-\mathrm{NH}_{2} \cdot \mathrm{HBr}$ groups and with $\mathrm{Br}^{-}$counter anion. The product yields ranged from 68 to 92 as shown in Table 1 which also includes ${ }^{1} \mathrm{H} N M R,{ }^{13} \mathrm{C} \mathrm{NMR}$, and FT-IR spectroscopic data.

A representative FT-IR spectrum, ${ }^{1} \mathrm{H}$ NMR and ${ }^{13} \mathrm{C}$ NMR spectra of compound $\mathbf{1}$ are shown in Figures 3a, $3 \mathrm{~b}$ and 4 , respectively. The FT-IR spectra of these

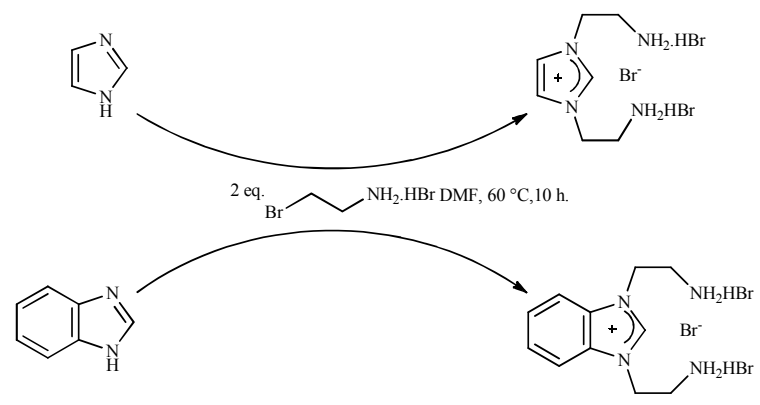

Scheme 1. One step DMF method for synthesizing symmetrical NHC salts.
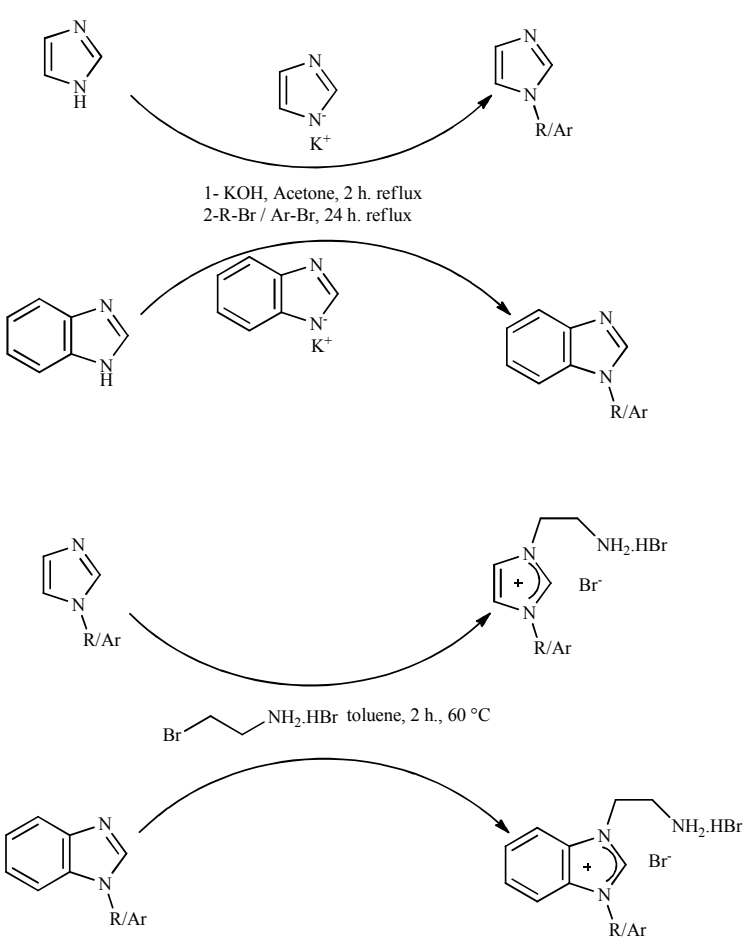

Scheme 2. Sequential method for synthesizing dissymmetrical NHC salts. compounds confirm the presence of the $-\mathrm{NH}_{2} \cdot \mathrm{HBr}$ groups from the broad peak in $2400-3500 \mathrm{~cm}^{-1}$. The peaks at $\sim 2970 \mathrm{~s} \mathrm{~cm}^{-1}$ and $2930 \mathrm{~s} \mathrm{~cm}^{-1}$ correspond to methyl and

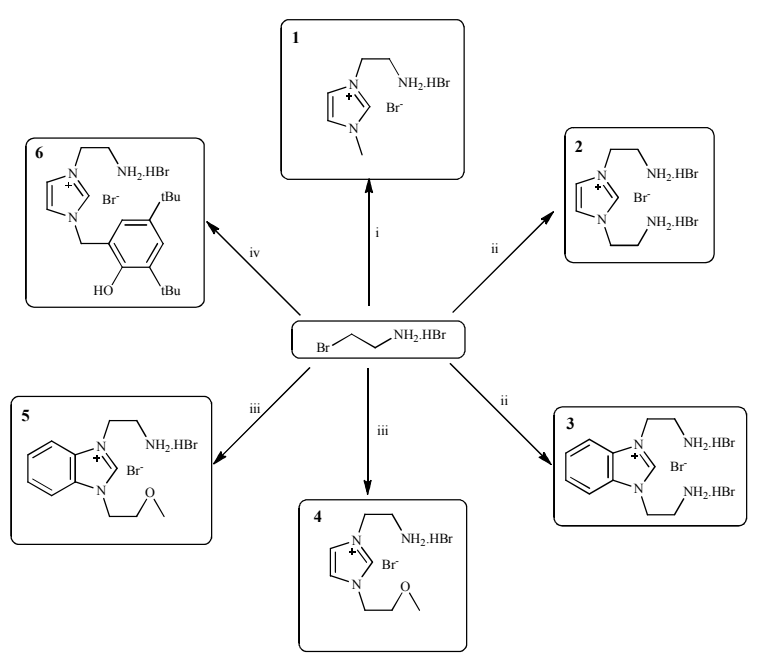

Scheme 3. Synthesize routes for the ILs concerned in this study: i: $\mathrm{N}$-methylimidazole, toluene, $2-3 \mathrm{~h}, 50-60^{\circ} \mathrm{C}$; ii: imidazole or benzimidazole, DMF, $10-12 \mathrm{~h}, 50-60^{\circ} \mathrm{C}$; iii: 1-(2-methoxyethyl)-1H-imidazole/benzimidazole, 2-3 h, 50-60 ${ }^{\circ} \mathrm{C}$; iv: 2-((1H-imidazol-1-yl)methyl)-4,6-di-tertbutylphenol, $3 \mathrm{~h}, 50-60^{\circ} \mathrm{C}$ ).
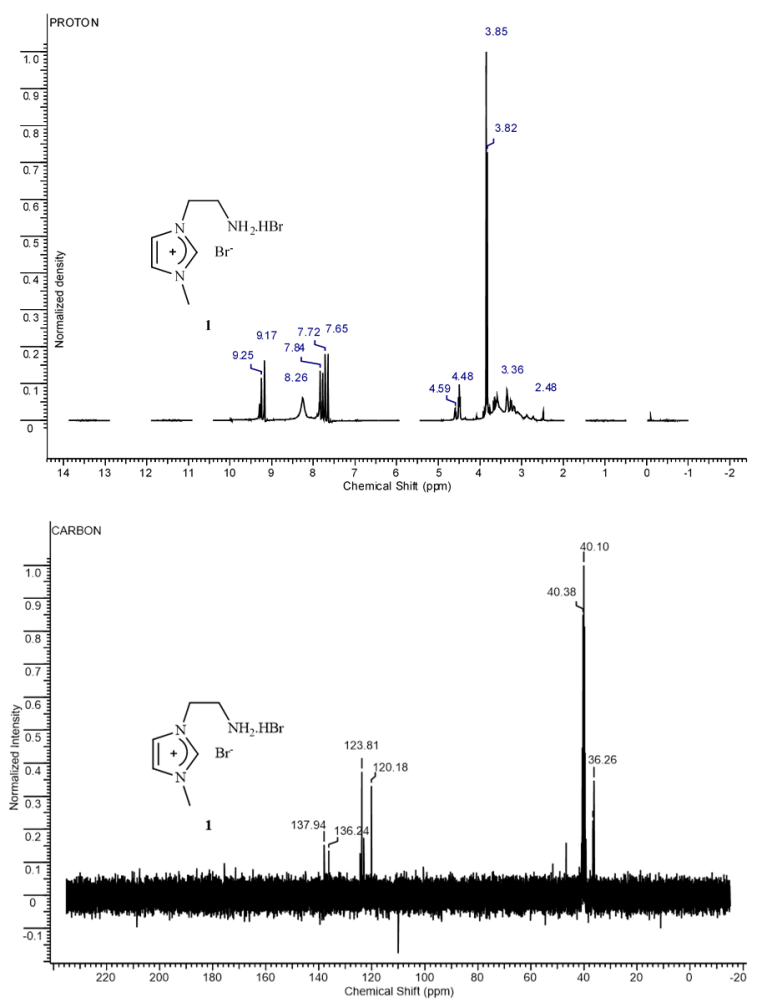

Figure $3 .{ }^{1} \mathrm{H}(\mathrm{a})$ and ${ }^{13} \mathrm{C}$ (b) NMR spectrum of IL 1. 


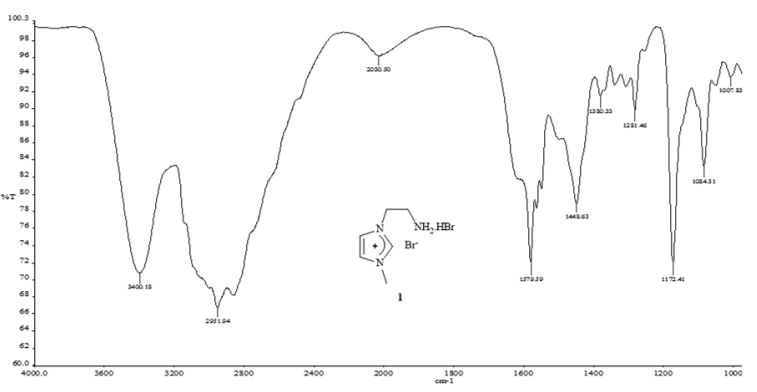

Figure 4. FT-IR spectrum of IL 1.

methylene $\mathrm{C}-\mathrm{H}$ bonds. The Amine, methyl and aromatic groups in the structures are consistent with the FT-IR spectra. Also, in the ${ }^{1} \mathrm{H}$ NMR spectra the two peaks in the acidic region show that $-\mathrm{H} . \mathrm{Br}$ groups in the compounds have not left the structure during the synthesize reactions. The experimental NMR and FT-IR spectra are in good agreement with the expected values and the structures of the synthesized NHC salts.

\section{Synthesis of Dis-Symmetric Compounds $1,4,5,6$}

To a solution of corresponding mono substituted imidazolium/benzimidazolium mid-product in toluene which contains $0.01 \mathrm{~mol}$ of mid-product, 1 eq. ( $2.05 \mathrm{~g}$ or $0.01 \mathrm{~mol}$ ) of 2-bromoethaneamine hydrobromide was added. The reaction mixture was heated $50-60^{\circ} \mathrm{C}$ with stirring for 2 or 3 hours. After cooling to room temperature, the solvent was distilled out under vacuum in a gas-vacuum manifold system. The reaction residue was washed with $5 \mathrm{~mL}$ of hexane three times and dried in vacuum, resolved in a minimum amount of $\mathrm{CH}_{2} \mathrm{Cl}_{2}$. The partially purified residue was washed with hexane again and hexane phase was removed by decantation. The residue was dried in a vacuum desiccator.

Table 1. Physical properties of the ILs 1-6.

\begin{tabular}{|c|c|c|c|c|c|c|c|c|c|c|c|c|c|}
\hline \multirow{3}{*}{$\begin{array}{c}\text { Compounds } \\
\text { Formulae }\end{array}$} & \multicolumn{13}{|c|}{ Chemical and Physical Properties } \\
\hline & \multirow{2}{*}{$\mathrm{Mw}$} & \multicolumn{4}{|c|}{${ }^{1} \mathrm{H}$ NMR Shifts } & \multicolumn{4}{|c|}{${ }^{13} \mathrm{C}$ NMR Shifts } & \multirow{2}{*}{$\begin{array}{l}\text { Solubility } \\
\text { in water }\end{array}$} & \multirow{2}{*}{$\begin{array}{c}\text { Physical } \\
\text { situation } \\
\text { or melting } \\
\text { point }\end{array}$} & \multirow{2}{*}{$\begin{array}{l}\text { Selected } \\
\text { FT-IR } \\
\text { Values / } \\
\mathrm{cm}^{-1}\end{array}$} & \multirow{2}{*}{$\begin{array}{c}\text { TLC } R_{\mathrm{f}} \\
\text { (acetone : } \\
\text { THF 1:1) }\end{array}$} \\
\hline & & $\mathrm{C} 2$ & Back1 & Back2 & Tale & $\mathrm{C} 2$ & Back1 & Back2 & Tale & & & & \\
\hline $1 \underset{\substack{\mathrm{N} \\
\mathbf{N}}}{[1+)\rangle}$ & 287 & 9.173 & 7.724 & 8.254 & 4.496 & 179.312 & 123.080 & 124.459 & 40.096 & Good & Liq. & $\begin{array}{l}3400.18, \\
2951.94, \\
1579.59, \\
1172.41\end{array}$ & 0.28 \\
\hline 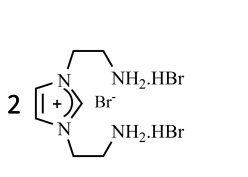 & 417 & 9.076 & 7.800 & 7.593 & 3.607 & 179.082 & 119.826 & 134.675 & 39.832 & Good & Liq. & $\begin{array}{c}3423.04, \\
2934.85, \\
1640, \\
1387.94, \\
1099.21\end{array}$ & 0.6 \\
\hline $\begin{array}{l}\mathrm{I}_{2} \cdot \mathrm{HBr} \\
\mathrm{I}_{2} \cdot \mathrm{HBr}\end{array}$ & 467 & 9.659 & 7.748 & 7.484 & 3.637 & 179.717 & 127.729 & 130.840 & 39.961 & Good & Liq. & $\begin{array}{l}3312.10, \\
2763.85, \\
1650.84, \\
1386.94, \\
1097.69\end{array}$ & 0.55 \\
\hline $4\left[\frac{1}{+}\right.$ & 331 & 9.208 & 7.772 & 7.662 & 3.652 & 179.364 & 120.502 & 124.297 & 40.312 & Good & Liq. & $\begin{array}{c}3349.29, \\
2942.18, \\
1655.42, \\
1388.73 \\
113.71\end{array}$ & 0.44 \\
\hline $\begin{array}{l}\mathrm{NH}_{2} \cdot \mathrm{HBr} \\
-\mathrm{O}\end{array}$ & 381 & 9.823 & 8.257 & 8.727 & 3.739 & 180.126 & 114.315 & 116.034 & 40.677 & Good & $43-45^{\circ} \mathrm{C}$ & $\begin{array}{l}\text { 3463.33, } \\
3021.00, \\
1561.18, \\
1117.11\end{array}$ & 0.33 \\
\hline${ }_{\mathrm{HO}}^{\mathrm{Bu}}$ & 491 & 9.138 & 7.710 & 7.966 & 4.873 & 179.560 & 120.031 & 136.232 & 40.127 & $\begin{array}{c}\text { Less than } \\
\text { others }\end{array}$ & $67-69^{\circ} \mathrm{C}$ & $\begin{array}{c}3490, \\
2952.54, \\
2868.03, \\
1575.33 \\
1361.38 \\
1003\end{array}$ & .078 \\
\hline
\end{tabular}




\section{Synthesis of Symmetric Compounds 2,3}

To a solution of imidazole/benzimidazole in DMF, which contains $0.01 \mathrm{~mol}$ of starting material, 2 eq. (4.1 g or $0.02 \mathrm{~mol}$ ) of 2-bromoethaneamine hydrobromide was added after stirring for $20-30 \mathrm{~min}$. The reaction mixture was heated $50-60^{\circ} \mathrm{C}$ with stirring for 10 or 12 hours. After cooling them to room temperature, the products (compounds $\mathbf{2}$ and $\mathbf{3}$ ) were exposed to the same purification procedure with dis-symmetric compounds.

\section{Antimicrobial Activities of ILs}

In vitro antimicrobial activity of the compounds (1-6) were tested against microorganisms including three gram-positive, three gram-negative bacteria and three yeast strains The biological methods for cultivation of bacterial strains and determination of antimicrobial activity have been carried out according to CLSI. ${ }^{[34]}$ The growth of the microorganism was determined visually; the first well observed no visible growth was determined as the MIC. All experiments were performed in triplicate. All results have been given in Table 2 .

\section{CONCLUSIONS}

The antimicrobial activities of six imidazolium derivative compounds were determined on six different bacterias and three yeasts. MIC values determined for ILs are given in Table 1. We observed that approximately all of compounds have a small antimicrobial activity against gram-negative bacteria, whereas, MIC values of all samples against
S. aureus $\left(4 \mathrm{mg} \mathrm{L}^{-1}\right)$ were promising. All of the compounds were shown better antimicrobial activity against the yeasts compared to the bacterial strains. Among them compound $\mathbf{1}$ showed a significant antimicrobial activity against to both bacterias and yeasts compared to other compounds (2-6). Also, compound $\mathbf{3}$ was effective towards only gram-negative bacteria, $P$. aeruginosa and yeast $C$. tropicalis in relatively lower concentrations. Compound $\mathbf{6}$ exhibited considerable activity with all yeasts at lower concentrations. Any considerable antimicrobial activities were not observed for compound 2, 4, 5 and $\mathbf{6}$ at the highest concentration $\left(4,0 \mathrm{mg} \mathrm{L}^{-1}\right)$. As an interesting outcome, the compound 1 exhibited better MIC values at a wide range of concentration (1-4 $\mathrm{mg} \mathrm{L}^{-1}$ ) despite its simplicity.

In summary, six different water soluble NHC salts were synthesized in high yields and structurally analyzed. Also, their antimicrobial activities were examined. All synthesized compounds showed antimicrobial activities while the compound $\mathbf{1}$ is still the best among the others. We believe that this result might safely be attached to the fact that the compound $\mathbf{1}$ is the smallest one. The smaller molecules can penetrate into the cell through the membrane and damage the organelles. As a matter of fact, our results can be looked down according to MIC values. However, it should be considered that an antimicrobial is not only used as medicine but also, it is quite useful for daily use such as surface disinfection and in agricultural practices. Also, these substances can be further investigated for drug delivery systems, and they will give synergetic profits in use.

Table 2. MIC values (mg L $\left.\mathrm{L}^{-1}\right)$ for ILs.

\begin{tabular}{|c|c|c|c|c|c|c|c|c|}
\hline \multirow{3}{*}{ Microorganism } & \multicolumn{8}{|c|}{$\mathrm{MIC} / \mathrm{mg} \mathrm{L}^{-1}$} \\
\hline & \multicolumn{6}{|c|}{ Compounds } & \multirow{2}{*}{ Gentamicin } & \multirow{2}{*}{ Nystatin } \\
\hline & 1 & 2 & 3 & 4 & 5 & 6 & & \\
\hline \multicolumn{9}{|l|}{ Gram positive bacteria } \\
\hline Staphylococcus aureus & $>4.0$ & $>4.0$ & $>4.0$ & $>4.0$ & $>4.0$ & $>4.0$ & 0.008 & n.t. ${ }^{(a)}$ \\
\hline Enterococcus faecium & 2 & $>4.0$ & $>4.0$ & $>4.0$ & $>4.0$ & $>4.0$ & 0.008 & n.t. ${ }^{(a)}$ \\
\hline Bacillus subtilis & 2 & $>4.0$ & $>4.0$ & $>4.0$ & $>4.0$ & $>4.0$ & 0.0005 & n.t. ${ }^{(a)}$ \\
\hline \multicolumn{9}{|l|}{ Gram negative bacteria } \\
\hline Escherichia coli & 4 & $>4.0$ & $>4.0$ & $>4.0$ & $>4.0$ & $>4.0$ & 0.001 & n.t. ${ }^{(a)}$ \\
\hline Salmonella typhimurium & $>4.0$ & $>4.0$ & $>4.0$ & $>4.0$ & $>4.0$ & $>4.0$ & 0.002 & n.t.(a) \\
\hline Pseudomonas aeruginosa & 4 & $>4.0$ & 2 & $>4.0$ & $>4.0$ & $>4.0$ & 0.0005 & n.t. ${ }^{(a)}$ \\
\hline \multicolumn{9}{|l|}{ Yeasts } \\
\hline Candida albicans & $>4.0$ & $>4.0$ & $>4.0$ & $>4.0$ & $>4.0$ & 2 & n.t. ${ }^{(a)}$ & 0.006 \\
\hline Candida krusei & 1 & 4 & $>4.0$ & 4 & 2 & 2 & n.t. ${ }^{(a)}$ & 0.003 \\
\hline Candida tropicalis & 1 & 1 & 4 & 2 & 2 & 0.5 & n.t. (a) & 0.006 \\
\hline
\end{tabular}


Acknowledgment. Financial supports by the Technological and Scientific Research Council of Turkey (TUBITAK 112T806) are gratefully acknowledged by the authors.

Appendix A. Supplementary Material.

Supplementary data also can be found in the supplementary material file named "suppkunduracioglu2014.docx" and "suppkunduracioglu2014.pdf." Also, NMR and FT-IR source files and pictures of spectra can be found in "suppkunduracioglu2014.rar" file too.

\section{REFERENCES}

[1] Y. Yu, Y. Nie, J. Environ. Prot. 2011, 2, 298.

[2] L. Weiwei, L. Cheng, Y. Zhang, H. Wang, M. Yu, J. Mol. Liq. 2008, 140, 68

[3] N. Bicak, J. Mol. Liq. 2005, 116, 15.

[4] N. P. Novoselov, E. S. Sashina, O. G. Kuz'mina, S.V. Troshenkova, Rus. J. Gen. Chem. 2007, 77, 1395.

[5] J. Safarov, R. Hamidova, M. Stephan, N. Schmotz, I. Kul, A. Shahverdiyev, E. Hassel, J. Chem. Thermodyn. 2013, 67, 181.

[6] C. Yue, D. Fang, L. Liu, T.F. Yi, J. Mol. Liq. 2011, 163, 99.

[7] A. R. Hajipour, F. Rafiee, J. Iran. Chem. Soc. 2009, 6, 647.

[8] K. Zhang, M. Conda-Sheridan, S. Cooke, J. Louie, Organometallics 2011, 30, 2546.

[9] J. W. Lee, J. Y. Shin, Y. S. Chun, H. B. Jang, C. E. Song, S. G. Lee, Acc. Chem. Res. 2010, 43, 985.

[10] S. Menne, J. Pires, M. Anouti, A. Balducci, Electrochem. Commun. 2013, 31, 39.

[11] M. Anouti, A. Mirghani, J. Jacquemin, L. Timperman, H. Galiano, lonics 2013, 19,1783.

[12] A. C. Franzoi, D. Brondani, E. Zapp, S. K. Moccelini, S. C. Fernandes, I. C. Vieira, J. Dupont, Quim Nova 2011, 34, 1042.

[13] M. Bendova, Z. Wagner, Fluid Phase Equilib. 2009, $284,80$.

[14] C. Hardacre, J. D. Holbrey, M. Niyuwenhuyzen, T. G. A. Youngs, Acc. Chem. Res. 2007, 40, 1146.

[15] M. Smiglak, A. Metlen, R. D. Rogers, Acc. Chem. Res. 2007, 40, 1182.

[16] Y. C. Hudiono, T. K. Carlisle, A. L. LaFrate, D. L. Gin, R. D. Noble, J. Membr. Sci. 2011, 370, 141.

[17] L. A. Neves, J. G. Crespo, I. M. Coelhoso, J. Membr. Sci. 2010, 357, 160 .

[18] M. Fouladgar, H. Karimi-Maleh, Ionics 2013, 19, 1163.
[19] N. Tian, X. Ni, Z. Shen, React. Funct. Polym. 2016, 101, 39.

[20] A. Kascatan-Nebioglu, M. J. Panzner, C. A. Tessier, C. L. Cannon, W. J. Youngs, Coord. Chem. Rev. 2007, $251,884$.

[21] H. Ohno, K. Fukumoto, Acc. Chem. Res. 2007, 40, 1122.

[22] S. Diez-Gonzalez, N. Marion, S. P. Nolan, Chem. Rev. 2009, 109, 3612.

[23] J. N. Pendleton, B. F. Gilmore, Int. J. Antimicrob. Ag. 2015, 46, 131.

[24] H. Turkmen, N. Ceyhan, N. U. Karabay-Yavasoğlu, G. Ozdemir, B Cetinkaya, Eur. J. Med. Chem. 2011, 46, 2895.

[25] X. Fu, L. Pu, J. Wang, Z. Zhong, lonics 2010,16, 51.

[26] T. J. Siciliano, M. C. Hindi, K. M. Deblock, S. Durmus, M. J. Panzner, C. A. Tessier, W. J. Youngs, J. Organomet. Chem. 2011, 696, 1066.

[27] A. Melaiye, R. S. Simons, A, Milsted, F. Pingitore, C. Wesdemiotes, C. A. Tessier, W. J. Youngs, Med. Chem. 2004, 47, 973.

[28] K. M. Hindi, A. J. Ditto, M. J. Panzner, D. A. Medvetz, D. S. Han, C. E. Hovis, J. K. Hilliard, J. B. Taylor, Y. H. Hun, C. A. Tessier, L. C. Cannon, W. J. Youngs, Biomaterials 2009, 30, 3771.

[29] A. R. Knapp, M. J. Panzner, D. A. Medvetz, B. D. Wright, C. A. Tessier, W. J. Youngs, Inorg. Chim. Acta 2010, 364, 125.

[30] A. E. Stine, D. Nassar, J. K. Miller, C. B. Clemons, J. P. Wilber, G. W. Young, Y. H. Yun, C. L. Cannon, J. G. Leid, W. J. Youngs, A. Milsted, Math. Biosci. 2013, 244, 29.

[31] S. Roland, C. Jolivalt, T. Cresteil, L. Eloy, P. Bouhours, A. Hequet, V. Mansuy, C. Vanucci, J. M. Paris, Chem. Eur. J. 2011, 17, 1442.

[32] S. Pardeshi, V. D. Bobade, Bioorg. Med. Chem. Lett. 2011, 21, 6559.

[33] S. N. Gavade, V. L. Markad, K. M. Modam, M. S. Shingare, D. V. Mane, Bioorg. Med. Chem. Lett. 2012, 22, 5075 .

[34] N. Iwai, K. Nakayama, T. Kitazume, Bioorg. Med. Chem. Lett. 2011, 21, 1728.

[35] M. M. Gonzalez-Chavez, F. Mendez, R. C. Martinez Perez-Gonzalez, F. Martinez-Gutierrez, Molecules 2011, 16, 175.

[36] CLSI (Clinical and Laboratory Standarts) Performance standarts for antimicrobial susceptibility testing. $17^{\text {th }}$ Informational Supplement, M100-217, 2007, 27, 1. 